\title{
Academy divided over new agreement
}

Washington

THE US National Academy of Sciences (NAS) is coming under increased criticism for negotiating a renewed scientific exchange agreement with the Soviet Academy of Sciences last January. Details of the agreement, which is still awaiting ratification by the Soviets, are being kept secret by the academy, which has intensified the uneasiness of groups working on behalf of Soviet refusniks and dissidents.

Shortly before the NAS annual meeting last month, a letter, signed by Christian Anfinsen, Paul Flory and Arno Penzias, was sent to all academy members, challeng ing both the wisdom and the morality of the move to reestablish ties. (The letter was subsequently published in Science 228, 530; 1985). Anfinsen et al. asked what had changed "to explain the about-face from the moral stance of 1980", when NAS broke off relations with the Soviet Academy in protest at the internal exile of Andrei Sakharov.

The three said Sakharov's condition had in fact worsened, and, citing NAS's own Committee on Human Rights, that there had been many new arrests of scientists. "To have held the negotiating meeting in Moscow", they concluded, "makes it hard to avoid an unfortunate hat-in-hand image."

A sharper challenge has come from Sakharov's son-in-law, Efram Yankelevich, who is living in the United States. After seeing Dr Frank Press, president of NAS, Yankelevich wrote an impassioned letter, taking Press and the academy to task in the strongest terms for having abandoned his father-in-law. The letter has been widely circulated within the scientific community.

Finally, Richard Perle, the hard-line Assistant Secretary of Defense for international security policy, broke government silence on NAS's actions with a strong criticism of his own. Speaking at a press forum arranged by the Scientists Institute for Public Information in Washington, Perle said that he was "disappointed that NAS is plunging ahead" with renewing exchanges. He argued the familiar administration line that the Soviets gain more from such exchanges than does the United

\section{Correction}

IN the graph illustrating the percentage of approved extramural research grants that are awarded by the National Institutes of Health (Nature May 9, p.88), the units on the right-hand axis were incorrectly specified. The range covered should have been from 30 per cent to 60 per cent, not from 3 per cent to 6 per cent.
States.

There is little doubt that Press has the support of the NAS membership, but these attacks have put him on the defensive. Press said last week that the differences between him and his critics amounted to a disagreement over tactics for aiding the refusniks and dissidents. He argued that, without face-to-face contacts, NAS's leverage is "non-existent". He said that "sending telegrams that are never even acknowledged may ease people's consciences, but there's no proof they've done any good",

Asked about reports from refusniks that their situation has worsened since he signed the agreement in Moscow (see the letter from Solomon Al'ber in Nature, 2 May, p.10), Press said that he had heard "contrary information" from his sources. And a source familiar with the negotiations said that NAS had demanded considerable concessions, including mention of the Helsinki accord in the text of the protocol. Academy officials have also let it be known that a part of the NAS delegation that went to Moscow met with refusniks there; Press himself did not, however.

As for Perle's criticisms, Press said that "he should have asked me what happened in Moscow before he made those remarks", remarks Press characterized as "intemperate".

Press said that Perle had not taken advantage of the opportunity to be briefed about the agreement (as were State Department officials and the US Ambassador in Moscow).

Press also rejects complaints about the secrecy of the document. He said that it is still in draft form and cannot be made public until negotiations have been completed and the text has been agreed by the Soviets.

Stephen Budiansky

\section{Sakharov}

\section{Resignation from Soviet academy}

\section{Ottawa}

THE Ottawa review conference of human rights performance by the 35 signatory countries of the Helsinki Final Act opened last week to a flurry of rumours that Academician Andrei Sakharov and his wife, Elena Bonner, have received permission to emigrate.

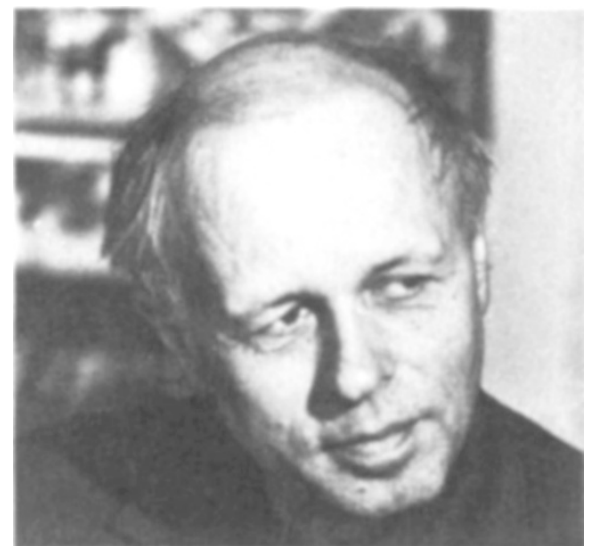

These rumours, which did little to defuse the procedural hassles that delayed the formal opening of the conference by several hours, so far remain unconfirmed.

Almost simultaneously came the news, confirmed by Dr Efrem Yankelevich, Mrs Bonner's son-in-law, who acts as Dr Sakharov's personal representative in the West, that Dr Sakharov had announced his intention of resigning from the Academy of Sciences of the USSR, with effect from $10 \mathrm{May}$, if his conditions of exile are not improved, and if Mrs Bonner is not allowed to travel abroad for medical treatment.

Although the Soviet authorities have, on several occasions, tried to pressurize the academy into expelling Dr Sakharov, these (C) 1985 Nature Publishing Group efforts have been resisted even by party hard-liners in the academy as liable to set a dangerous precedent. Dr Sakharov's voluntary resignation, however, would clearly not be in the interests of the authorities, in view of the considerable comment it would arouse internationally.

Moreover, Dr Sakharov, who will be 64 on 21 May, is past Soviet pensionable age, and the loss of his academy stipend, which he has still been permitted to draw, would not necessarily put him at risk of a charge of "parasitism" (being without visible means of support). Dr Sakharov has previously been reluctant to leave the Soviet Union, feeling that his presence there provides valuable moral support for the human rights movement and for victims of oppression. Hence in 1975, he did not collect his Nobel peace prize in person for fear that he would not be allowed to return to the Soviet Union. Since he was exiled to Gor'kii in January 1980, he has been effectively prevented from giving any assistance to his distressed fellow-citizens, and in 1983 he accepted an invitation from the Norwegian government to settle in Norway - provided, of course, that he is allowed to leave the Soviet Union.

Prospects for the Sakharovs to emigrate are not, however, promising. According to Dr Yankelevich, Mrs Bonner, who was sentenced to three years' internal exile to Gor'kii in August 1984, was excluded from the amnesty proclaimed in honour of the fortieth anniversary of the end in Europe of the Second World War. Dr Sakharov's own exile, of course, is the result of an administrative decision and, technically speaking, has no legal validity.

Vera Rich 